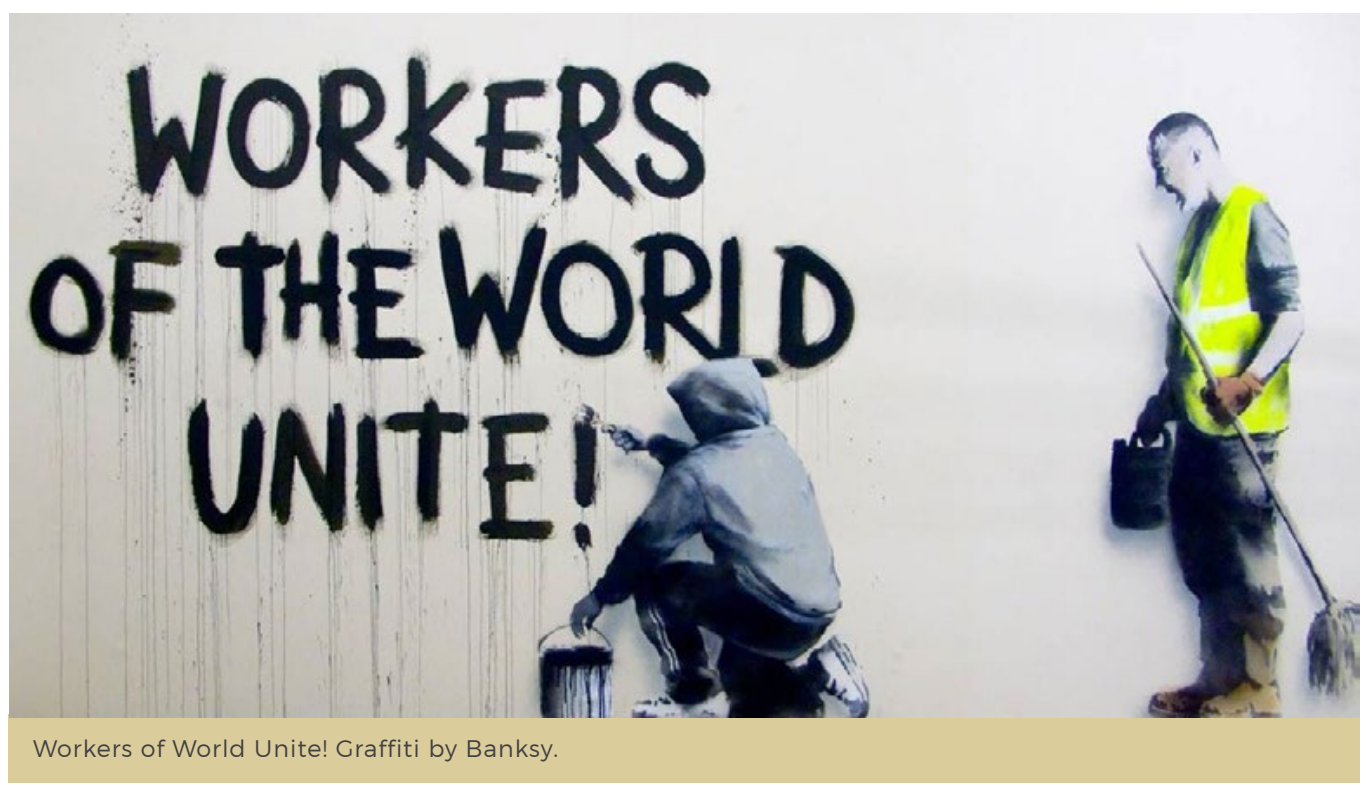

\section{A Genealogy of Precarity and Its Ambivalence}

\section{Francesca Coin}

Focussing on the conceptual evolution of precarious labour over the past three decades, this essay provides a genealogy of the notion of precarity. On the eve of the fourth industrial revolution, when precarity has become the norm and fears of a jobless society have alimented a dystopian imaginary for the future, this historical reconstruction seeks to identify those elements that have shaped the material conditions of workers as well as influenced their capacity for endurance in times of growing uncertainty.
My generation-or probably most individuals who were born since the late 1970s-has often perceived precarity as a generational curse, and looked at Fordism as a time of social and labour stability. On the contrary, Brett Neilson and Ned Rossiter's article Precarity as a Political Concept, or, Fordism as Exception (2008) reminds us that for us to understand precarity, we must move beyond such approaches to see Fordism as an exception and precarity as the norm. In fact, the 1960s and 1970s were decades of uncertainty. The Federal Reserve's monetarist experiment in 1979 transformed labour into an adjustment variable of its monetary policy. In this context, the de-standardisation of salaries and the individualisation of contract relationships came with an overall transformation of governance and labour management that tied income to profit and transformed labour into the shock absorber for capital risk. Since then, casualisation of employment, insecure income, and labour dislocation became the defining traits of labour relations (Marrazzi 2008). Time softens the hard edges in our memories, but accounts from those years 
provide descriptions of a society in turmoil, mired by plant foreclosures and rampant job losses.

In the United States, the monetarist experimentsuddenlybrought unemployment to levels unseen since the Great Depression. In several cities, manufacturing plants that had been the symbol of industrial growth either shut down, introduced severe cuts in the workers' salaries, or started laying off employees (Toland 2012). Modernity seemed to be going downhill rapidly. In several industrial cities, unemployment peaked at over 20 percent in the early 1980s, often leading people to flee to other places to find work. In some instances, manufacturing jobs vanished into obsolescence due to technological changes; in others, they drifted overseas in the search for cheaper labour. In retrospect, we know that what was happening was a major global restructuring of labour relations (Toland 2012). Over the past decades, the increase in productivity allowed by science and innovation became the catalyst for a transformation in labour relations characterised by a growing distance between emerging clusters of high-tech industries and the Global South's dependency on technologically advanced multinational corporations. Inequality was not limited to macroeconomics but was reflected in the growing cleavage between a higher rank of high-tech specialists and a growing reserve of low-skilled precarious workers.

\section{The Experience of the Italian Autonomia}

During the 1960s and 1970s, the Italian leftist movement autonomia turned to Marx's Grundrisse (1973) to define this transition. In this work, Marx foresaw that innovation and technology would become a direct force of production and allow employers to become relatively independent of the labour force. In other words, capital could use 'the inanimate limbs' of science and technology to restrict necessary labour, hence transforming innovation into a curse likely to increase unemployment and social insecurity. At the same time, the purpose of technology would not only be the limited to the accumulation of wealth. On the contrary, the general intellect could use technology to improve the conditions of production and liberate time-what Marx defined as 'the general reduction of the necessary labour of society to a minimum, which then corresponds to the artistic, scientific etc. development of the individuals in the time set free.' The fact is that the 'inanimate limbs' of science are not outgrowths of nature, Marx warned. 'They are organs of the human brain, created by the human hand, and in this sense 'they are the material conditions to blow this foundation sky-high'.

During the 1960s and 1970s, these prophetic words became the distinctive tune of a generation. The diffuse intellectuality that took to the streets turned to the Grundrisse to decipher the historical transition they were enduring. No longer wanting to be constrained within the space and time of the plant, Italian autonomia posited itself as an embodiment of the 'general intellect' that felt an urge to liberate society from its chains. The simplicity of their slogans beautifully explains the complexity of their interpretation.

'Zero work for income

Automate all production

All power to living labor

All work to dead labor'

'The revolution is over, we've won'

A/traverso, 1977 (Berardi 2009, 25-26)

Despite the cultural distance that separates us from those years, it must be said that recent literature has rediscovered 
those perspectives. From Nick Srnicek and Alex Williams' Inventing the Future: Postcapitalism and a World without Work (2016) to Paul Mason's Postcapitalism: A Guide to Our Future (2015), intellectuals have turned to these interpretations in order to compensate for today's social and political impasse. Liberation from labour and the 'struggle to be human and educated during one's free time', emerge in Mason's analysis as the vision of a post-capitalist society that can grow inside the old one.

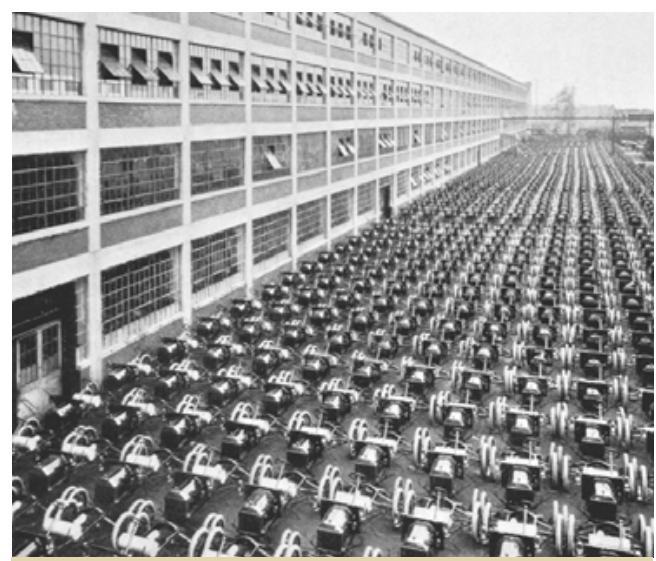

Highland Park Ford Plant, the first factory in history to assemble cars on a moving assembly line. Photo: AutoTraderClassics.com

\section{From Utopia to the Race to the Bottom}

The problem in these visions is that they never came true, and the enchanting idea of a world free from work left room for a generalised race to the bottom where labour was often not only unfree but unpaid. The transition to post-Fordism could be defined as a general dismantling of the time and space boundaries established by Fordism. According to Antonio Negri (1984), the mass worker that characterised the years of Fordism gave way to the 'social worker'an individual whose life was entirely put to work. While industrial capitalism was founded on large factories, specialised in the production of mass, standardised goods and marked by a clear separation between the time of production and the time of consumption, post-Fordism annihilated such divisions (Vercellone 2005). In the social factory, the creation of value extended beyond the factory walls to embrace the whole of society.

In this context, the question became what type of organisational mechanisms of control could be used to supervise a labour force that was ever more fluid and free to move beyond space and time constriction. In 1978-1979, Michel Foucault's course at the Collège de France, La naissance de la biopolitique (Foucault and Senellart 197879), analysed how the breakup of time and space constrictions that was typical of a disciplinary society transformed governance and management. In a postFordist society, governance became micropolitical and used new techniques to enforce discipline. Deleuze spoke of a 'society of control' characterised by the use of salaries to justify the coercion of individuals into a new relation of dependence (1992). In this context, precarity became 'the growing insecurity brought on by the flexible management of the global work force within post-Fordist capitalism' (Brophy 2006, 622). Today's Uber drivers or social media 'prosumers', in some instances, embody this shift. The notion of the 'prosumer' refers to the 'progressive blurring of the line that separates producer from consumer' (Toffler 1980, 267), a definition that is often used to describe 'prosumer capitalism' and the management's attempt to outsource informal labour to consumers-a mechanism that defines both corporations such as Ikea and the political economy of social media. The progressive blurring of the line that separates leisure and work, as well as production and consumption, have come to define a type of capitalism 
marked by precarity-as manifested in the proliferation of temporary and casual labour, delocalisation and subcontracting, occasional labour, labour on demand, and unpaid work.

\section{The New Dangerous Class?}

Over the past ten years, the representation of precarity has been ambivalent. In his widely discussed book, Guy Standing describes the precariat as 'the new dangerous class' and maintains that the precariat is not merely a distinctive socioeconomic group but rather a neologism that combines an adjective 'precarious' and a related noun 'proletariat', to describe 'a class-in-the-making, if not yet a class-foritself, in the Marxian sense of that term' (2011, 19). Standing's representation of precarity refers to the early 2000s. During the 2005 May Day protest in Milan, for example, over one hundred thousand people took to the streets to voice the needs of the global precariat. These very assemblies and moments of collective action were considered pivotal in globalisation politics and crucial for the precariat to find its own voice. In her genealogy of precarity, Maribel Casas-Cortés looks at the activist networks that emerged in those years as 'a Deleuzian politics of unfixed alliances' that transformed the precariat into a political subject capable of intertwining identities and demands $(2014,220)$. In this sense, she drafts a set of concepts that could agglomerate social groups-from immigrants to young, educated locals-and a set of demands to be posed to governments. Intertwining the struggles of migrants, women, and precarious workers, Maribel Casas-Cortés argues that precarity seemed to represent a strategic political proposal intended to use Deleuze's 'tool box' to change society, as maintained by a EuroMayDay organiser that she interviewed (2014, 221). At the same time, it is absolutely evident that there is a tremendous distance between those empowered accounts of precarity and the conditions of social insecurity that have continued to afflict labour over the years.

Today, employment insecurity has evolved into conditions even more challenging. The widespread use of unpaid labour in the 'internship economy' and the prospects of uncertainty accelerated by the gig economy, obscures the idea of the precariat as a dangerous class and emphasises the raising insecurity facing it. As I look at the labour market from the rotten heart of Southern Europe, I wonder whether the artificial description of precarity as a political subject did us any good. The bitterness of an unfulfilled revolution during the 1970s probably found comfort in representations of the precariat as a dangerous subject, but at the same time such narratives permitted a general underestimation of the violent forces confronting labour. It is going to take a very different sense of urgency and determination to reverse the conditions of exploitation that have become the new normal. 
This text is taken from Gilded Age: A Year of Chinese Labour, Civil Society, and Rights, Made in China Yearbook 2017, edited by Ivan Franceschini and Nicholas Loubere, published 2018 by ANU Press, The Australian National University, Canberra, Australia.

doi.org/10.22459/MIC.04.2018.01 